Vol. 15, $n^{\circ} 1$ | 2011

Varia

\title{
Communicating Colonial Order: The Police of German South-West-Africa (c. 1894-1915)
}

Jakob Zollmann

\section{(2) OpenEdition \\ Journals}

Electronic version

URL: https://journals.openedition.org/chs/1240

DOI: 10.4000/chs.1240

ISSN: 1663-4837

Publisher

Librairie Droz

Printed version

Date of publication: 1 May 2011

Number of pages: $33-57$

ISBN: 978-2-600-01515-8

ISSN: $1422-0857$

\section{Electronic reference}

Jakob Zollmann, "Communicating Colonial Order: The Police of German South-West-Africa (c.

1894-1915)", Crime, Histoire \& Sociétés / Crime, History \& Societies [Online], Vol. 15, n¹ | 2011, Online since 01 May 2014, connection on 22 March 2022. URL: http://journals.openedition.org/chs/1240 DOI: https://doi.org/10.4000/chs.1240 


\title{
Communicating Colonial Order The Police of German South-West-Africa (c. 1894-1915)
}

\author{
Jakob Zollmann'
}

\begin{abstract}
La police du Sud-ouest africain allemand (Namibie), composée d'environ 500 anciens sous-officiers allemands et 370 policiers africains, ne fut formellement créée qu'en 1905. Ses fonctions étaient analogues à celles de la police en Allemagne: maintenir l'ordre et la tranquillité publique et réprimer la délinquance. Les policiers coloniaux devaient également appliquer les «règlements indigènes» (Eingeborenen Verordnungen) de 1907, qui régissaient le port des cartes d'identité pour les Africains, ainsi que leurs obligations de travail et d'enregistrement auprès des autorités locales. L'effectivité de ce contrôle était cependant limitée, comme le montrèrent les vaines tentatives policières pour mettre un terme aux vols de bétail et autres formes de brigandage. En outre, ces policiers avaient du mal à communiquer avec la population et devaient recourir à des interprètes locaux dont la fiabilité leur était suspecte. Afin d'obvier cette difficulté, les policiers allemands furent requis d'apprendre une langue locale, mais cette obligation souleva de nombreuses difficultés et leurs efforts ne rencontrèrent qu'un succès très limité.
\end{abstract}

Being only formally founded in 1905, the police force of GSWA (consisting of roughly 500 former German NCOs and 370 African policemen) had duties similar to those of the police within Germany: to secure public order and the public's welfare, as well as to penalise perpetrators. In addition to these duties, colonial police officers also had to execute the so-called «native regulations» of 1907 (Eingeborenen-Verordnungen), which regulated the carrying of official passes by Africans, as well as their obligation to work and to be registered with the local administration. The actual ability of the colonial police force to exert control over the colonial territory was limited however, as futile attempts to bring an end to cattle theft and other forms of banditry were to demonstrate. Communication with the local population also proved to be a problem for these officers, with officials forced to refer to African interpreters whose reliability they questioned. In an attempt to circumvent this issue, German policemen were requested to learn an African language. In this the colonial police force would encounter many problems however, with their attempts producing only meagre results.

Jakob Zollmann studied history and law in Berlin, Paris and San Francisco. He works as a legal consultant and is author of a book on the colonial police force in GSWA: Koloniale Herrschaft und ihre Grenzen: Die Kolonialpolizei in Deutsch-Südwestafrika 1894-1915, Göttingen, Vandenhoeck \& Ruprecht, 2010. 


\section{INTRODUCTION}

$\mathrm{A}^{\mathrm{t}}$ the end of the $19^{\text {th }}$ century, colonial administrators began to introduce the policing duties and practices (for example regulating, punishing, informing and recording) that had evolved in Europe over the course of centuries to their colonial territories. These duties and practices were accepted as being necessary police functions in the maintenance of law and order within a (colonial) state, especially in those territories whose communities of settlers were growing. Furthermore, the accompanying division of colonial forces into military and police wings was not just a mere formality: it signalled the more rooted, stabilised, and indeed more "normalised' status of colonial power. It was in this context that Britain organized the Gold Coast Armed Police in $1865^{2}$. The German colonial empire was no exception to these developments.

Germany did not acquire colonies before 1884/5, and these acquisitions in Africa and the South Seas were at first barely touched by their new 'masters'. Historians talk of a " "paper occupation' of Africa" during the course of the Berlin Africa Conference ${ }^{3}$, and indeed a few engagements by one or two navy vessels off the coastline were all the German government initially afforded with regard to their new overseas possessions. Chancellor Otto v. Bismarck was reluctant when it came to the expensive deployment of troops in Germany's African territories, which (according to his plans) should not have been "colonies" proper, but instead protectorates (Schutzgebiete): territories administered privately by "British style" chartered companies ${ }^{4}$. His plans proved futile however, and so did hopes for Africans willingly accepting German "protection" - increasing 'riots' led to the deployment of more troops. Even with these increases, the numbers of men employed were still to remain small: in 1890, for instance, only 190 German troopers and 1530 Africans were deployed in German East Africa [now Tansania]. In 1893, only 220 men were deployed to German South-West-Africa [GSWA, now Namibia], in an effort to subdue the Ovaherero and Nama. Perhaps unsurprisingly given the number of troops deployed, it would ultimately be political machinations, rather than German military might, that would lead to the signing of "protection treaties" by African leaders like Samuel Maharero of Okahandja, or Hendrik Witbooi of Gibeon ${ }^{5}$.

It would only be in 1894, a full ten years after the tradesman Adolf Lüderitz had originally requested protection from the German Empire for his 'possessions' along the coastline of south western Africa, that some invalid German troopers as well as a few Africans would be seconded as policemen to the colonial capital Windhoek, as well as in the towns of Swakopmund and Keetmanshoop. Assigned to act as clerks for the local administration, they were tasked with helping control the growing 'urban population' of settlers and Africans as well as the farm areas.

Establishing a colonial (police) force was merely one aspect of German colonial policy however. The aims of the German colonial mission were manifold: apart from economic objectives, colonial missions claimed to be civilizing missions,

See Deflem (1994, p. 51).

Betts (1985, p. 314); Huber (1986, p. 609); Schildknecht (2000, pp. 75-196).

Canis (2004, pp. 222; 224); see Aydelotte (1970).

Tiebel (2008, 62, pp. 75-78); see Gewald (1999, p. 31f.); Kaulich (2001, p. 204ff.; 217f.); Südwest-

bote, 11. Jg. 29.05.1914, p. 3 . 
bringing order into chaos ${ }^{6}$. Colonial possessions «were meant to, at least in some respects, evolve into something resembling a state ${ }^{7}$. Irrespective of any discussion about colonies being used as "laboratories", the intention to establish a state-like order according to European patterns, including taxes, military, police, prisons, schools and infrastructure, was unmistakable. The question of how to reach these objectives remained open for contemporaries however: the resulting "colonial perplexity" of Europeans in Africa is to be emphasised".

By examining German efforts to regulate, control and communicate colonial order, the following analysis of attempts to police GSWA exemplifies this "colonial perplexity". The first part of this analysis, focusing on regulation and personnel, outlines: 1) how the legal and administrative framework of colonial policing was organized in GSWA; 2) how contemporaries dealt with, and how researchers have assessed, the effectiveness and/or impotence of German colonial rule; and 3) why the involvement of African personnel was indispensable for German colonial rule. The second part of this analysis puts an emphasis on colonial policing practices, exemplified by: 1) police patrols and 2) the interaction between police and the African population after the "native regulations" were enacted in 1907. In the third part of this study, the focus shall be on the languages used to communicate between Africans and German policemen in GSWA, in order to analyse: 1) the inadequacy of interpreters for colonial purposes; and 2) how German officials could be turned into African language students.

Over the last decades, such questions on the policing of German Africa have been, by and large, neglected in German historiography. Whereas considerable research on the policing of the British Empire has been undertaken, no comparable literature is available for the German colonies. The gaps that were left by the few authors who have worked in that field since the $1960 \mathrm{~s}$ - the most notable of these being Helmut Bley, Karin Hausen, Horst Gründer and Trutz v. Trotha - have increasingly been filled by the recent boom in the field of colonial history in German academia (and beyond). During the last ten years, numerous books and articles have contributed to a better understanding of German colonialism 'on the ground'; in addition, German colonial fantasies, desires, failures and limitations have also been under heightened scrutiny in recent times, and it is upon this base that this article will build.

\section{REGULATING COLONIAL POLICING}

\section{The administrative framework and police personnel in GSWA}

When Europeans began to colonise the African continent, they had little to no concept of how to achieve this objective. Knowledge about the areas to be colonized was lacking. Besides knowledge, infrastructural and financial means were also

\footnotetext{
6 Rafalski (1930); see Barth, Osterhammel (2005).

7 Chancellor Leo v. Caprivi Stenographische Berichte des Reichstags (SBRT), 8. Legislaturperiode, 1. Session. 1890/91, Vol. 1, 12.5.1890, p. 41.

8 Laak (2004, pp. 257-279); Blackbourn (2004, p. 332).

$9 \quad$ Harding $(2006$, p. 27f.).
} 
lacking, as well as personnel and the appropriate equipment with which to enter the unknown territories. Colonial administrators were forced to resort to policies of 'trial and error' in order to implement their self-imposed benchmark of (rudimentary) statehood. The development of German colonial law, starting in 1886, was certainly no exception to this 'trial and error' approach ${ }^{10}$.

The legal arrangements of colonial rule were necessary in order to meet the requirements of international and German constitutional law. Budgets had to be approved; officials were to be sent to the colonies; civil and penal jurisdictions had to be stipulated, as well as other competences. The Colonial Law (Schutzgebietsgesetz), passed by the parliament in 1886, was to form the legal foundation for an evergrowing realm of ordinances and some formal laws until 1918. The Colonial Law declared the Emperor to be the bearer of the state authority (Schutzgewalt) on behalf of the Reich. The definition of Schutzgewalt became highly contested by legal scholars in Imperial Germany, but generally it was accepted to mean the authority to govern the overseas territories. The Emperor was also entitled to delegate his power to the chancellor, who thereby became the "colonial minister". European contemporaries saw the development of a colonial administration as a stepping-stone towards the goal of establishing a 'state' inside a territory that was defined - according to international law - as terra nullius. The situation discovered in the colonies was - from a contemporary point of view - in need of a 'cultural' reconfiguration ${ }^{11}$. German legal provisions therefore had to be implemented in the colonies. The administration in Berlin ruled the colonies by ordinances, with the express desire of keeping parliament and its laws out of administering the colonies as far as possible ${ }^{12}$. More and more ordinances - specifically meant to meet the requirements of ruling a colony - were passed, starting with provisions against the sale of alcohol and weapons. The initial 'trial and error' policy of early colonial rule was replaced by a more stringent (legal) grip on colonial assets after 1900. The number of regulations continued to grow constantly, finally filling more than 13 volumes ${ }^{13}$.

The Kaiserliche berittene Landespolizei für Deutsch-Südwestafrika (Imperial mounted police force in GSWA) was a police institution militarily organized and trained, but administered by the civil administration. Its members were civil servants rather than soldiers. The head of the police inspectorate in Windhoek, however, was a Major or Lieutenant-Colonel delegated to serve in the civil colonial administration, and under the colonial governor. Given that questions relating to the subordination of military personnel under civil rule were of utmost importance to German contemporaries, it is remarkable that in German colonies (except for the naval base Tsingtao) the civilian governor headed not only the administration ( $\mathrm{Gou}$ vernement), but was also superior to the commander of the military (Schutztruppe), as well as to the head of the police inspectorate (Inspektion der Landespolizei) ${ }^{14}$.

After several previous attempts with civil policing, a police force in GSWA, distinct from the military, was formally founded in 1905. Based on plans made in 1903, and being founded during the wars against Ovaherero and Nama, this new police

\footnotetext{
10 See Grohmann (2001); Sippel (2001); Florack (1905).

11 See Koskenniemi (2000, p. 123f.); Blackbourn (2004, p. 318).

12 Pflanze (1998, p. 372).

13 Gerstmeyer, Köbner (1913).

14 Cf. Michels (2006); Huber (1986, p. 609).
} 
force was initially not to play a role in GWSA. As in previous years, the military continued to execute most of the police work; it would not be until 1907, following the formal introduction of the Emperor's organisational ordinance, that the business of recruiting and actual police work would begin. The missions and duties of the colonial police force were to be similar to its law enforcing counterparts in Germany: securing public order, protecting the public's welfare, and penalising perpetrators. In addition to these tasks, colonial police officers had to execute the socalled "native regulations" of 1907, which regulated the carrying of official passes by Africans, as well as their obligation to work and to be registered with the local administration; stipulations similar to those found in the neighbouring Cape Colony and Transvaal.

As stated above, the police inspectorate was a division within the governorate (Gouvernement) of GSWA, which was in turn subordinate to the Imperial Colonial Office (Reichskolonialamt) in Berlin. The police force was to comprise around 500 former non-commissioned officers (the military imprint of police officers was common in Imperial Germany, and in this case it was required that the prospective police officers had served in the colonial forces or German army for at least six years) and 370 African "police servants" (Polizeidiener). These policemen would be deployed in up to 110 police stations within, and at the fringes of, an established "police zone". This "police zone" was an area within GSWA (around 60\% of the territory, excluding the northern periphery of the colony as well as parts of the Kalahari and Namib desert) where European settlers were allowed to own land. With the German parliament passing cutbacks in colonial budgets, the intended expansion of colonial police capacity would be hindered: of the 720 German police sergeants planned for 1907, barely 450 could be actually budgeted for in 1913 (next to approximately 1,900 soldiers).

Despite continuous pressure on its budget, the above force would have to police the roughly 14,000 European settlers, mostly of German origin, that lived within GSWA by 1913. The precise number of Africans within the "police zone" of GSWA is hard to estimate. There are no exact population figures available from before the German wars against Ovaherero and Nama (1904-07), which, according to assessment of some researchers, annihilated more than $50 \%$ of the respective populations ${ }^{15}$. Also contemporary figures from after the war are unreliable - the 1908 estimate of Vice-governor Oskar Hintrager, who claimed that "the entire coloured population" of Africans within the "police zone" stood at 59,214 people, being a pertinent exam$\mathrm{ple}^{16}$. After all, who would have counted the population in this barren, often desertlike territory, larger in size than Germany? This figure can only be treated as an approximate value at best, and owes much more to a colonial fantasy of omnipotence than any real systematic study. Nevertheless, GSWA was still the largest settler community of all German overseas possessions; despite this fact, the economic expectations of most individual settlers, as well as the demographic hopes of policy makers and colonial enthusiasts, would be disappointed.

\section{Effectiveness and/or impotence of German colonial rule in GSWA}

The above quoted numbers can only serve to question the effectiveness of colonial rule, which was - especially outside the very small colonial 'towns' -

\footnotetext{
15 Krüger (1999, pp. 29-122); Gewald (1999, pp. 141-190); Eckl (2008).

16 Bundesarchiv Koblenz (BAK) N 1037/9, Die gesamte farbige Bevölkerung DSWA 1908.
} 
represented most of all by military personnel or policemen 'on the beat'. Any comparison between what was intended and what was executed emphasizes the deficits and limits of colonial rule, and also often the impotence and inability to rule the areas meant to be colonized. It was in this context that Jeffrey Herbst pointed to the "schizophrenic nature of colonial power in Africa": despite their brute force, colonial coercive powers were regularly unable to enforce colonial rule 'always and everywhere' within their colonial territories ${ }^{17}$.

As is true with colonial historiography in general, "a new generation of historians of colonial Namibia" also tend to question the "colonial hegemony"18. Indeed, questions on the weakness of the colonial state have been repeatedly posed, especially when looking at the colonial spaces: where and when was the colonial state actually present ${ }^{19}$ ? Considering the huge territories to be colonized, territories in which the colonial state was barely present, and particularly in view of the meagre colonial budgets and strategies of those who were being colonized, some historians have characterized colonial rule as a form of "weak" or "embryo government". This "impotent" colonial state has also been characterized (in its German version of GSWA) as a "pre-fascist" institution however ${ }^{21}$, which attempted the "total" surveillance of its colonised subjects, and was thus a forerunner to the practices of Nazi rule. The alleged "extreme nature of German colonial repression in Namibia""22 is referenced by the ideology and brutality of the German officials, as well as by the fatal results for both those Africans who rebelled, and more generally those who came into contact with the colonial state ${ }^{23}$.

Even when taking the undisputed brutality of the colonial state into account (the specificity or "extreme nature" of the German case has not yet been proven ${ }^{24}$ ), one still cannot ignore the fact that colonial officials were unsuccessful in their attempts to establish "peace and (public) order" in large tracts of their colonial territories. As L. Gann and Peter Duignan stated decades ago: "A totalitarian state requires a coercive state machine much more extensive and elaborate than that available to any colonial power in Africa." ${ }^{25}$ Colonial power was specifically located - and limited to a few places: colonial towns, police stations, and military outposts. The colonial state can thus be seen to have consisted of little more than a loosely connected " rag rug' of islands of colonial power" 26 , their connection to each other coming in the form of weekly or monthly patrols.

The colonial state at least attempted to be 'on the spot'. The demonstration of colonial presence was as much a problem as it was a task for colonial officials. The head of the Windhoek district stated in 1908 that his policemen's "main tasks consist of riding patrols, in order to remind the natives of the presence of armed forces

\footnotetext{
Herbst (2000, p. 58); see Eckert (2007, p. 17f.).

Dedering (2006, p. 275).

See Blackbourn (2004, p. 303).

Oliver (1985, p. 6f.); Pesek (2006, p. 117).

Helbig (1988).

Gewald (2001, p. 157); see Bley (1996, p. XVII)

Zimmerer (2001, pp. 183/5, 2004a, p. 285, 2004b, 2005, p. 48).

See Kundrus (2008, p. 30).

Gann, Duignan (1977, p. 238).

26 Pesek (2006, p. 132).
} 
and to provide protection to the surrounding farmers" 27 . It was clear to the supervisor just to what extent his policemen were able to exert influence over the "natives"; as Richard Roberts has remarked, "Colonial officials were usually keenly aware of the weakness of their own authority" 28 .

Until well into the $20^{\text {th }}$ century, European powers only insufficiently managed to secure 'their' colonial stakes. It is therefore correct to characterize - according to the self-imposed benchmark of European statehood - colonial governments, and their rule, as "weak" - a limitation that did not preclude the use of brutality however" The example of the German police force in GSWA supports this assumption. For 25 years (1890-1915), public security forces attempted to bring the territory under German control; for 25 years, pretence and reality diverged. As the above-quoted general assessment of colonial "embryo" or "weak government" 30 shows, this was in no way a German particularity. The British colonial administrators in Africa constituted little more than a "thin white line", and the same is true for their German counterparts $^{31}$. The Governor of GSWA, Theodor Leutwein, remarked that "the nominally existing German rule in the colony was not noticeable until 1891"32. Even the German colonial encyclopaedia stated that "only since 1907 one can speak of actual German rule" in GSWA ${ }^{33}$.

Nevertheless, pretence and reality would diverge later on. Some contemporaries of the post Herero- and Nama-Wars characterized GSWA as, according to European patterns, "completely pacified", and in a "state of order" ${ }^{34}$. The police files of the authorities in Windhoek suggest otherwise. The administration attempted to provide 'safety' for European settlers only inside the "police zone"; even there, however, "rustlers" and "robbers" continued to cause trouble. Many regulations were stipulated by the administration, but their enforcement was often impossible. Policemen regularly reported to their superiors about these challenges, declaring for example that tax collections in African settlements (cerft) were "unenforceable" 35 . Beyond the "police zone", in the so-called Caprivi-strip or in Ovamboland, the colonial state admittedly did not even exert any control over the territory, which nominally belonged to GSWA ${ }^{36}$.

\section{African colonial personnel}

Colonial administrators in Windhoek were familiar with their "weakness" in the field. In order to achieve their aim of creating a state according to European patterns, and to satisfy the necessity of ensuring order and security for any settlers, these colonial administrators required adequate and sufficient security personnel. With the

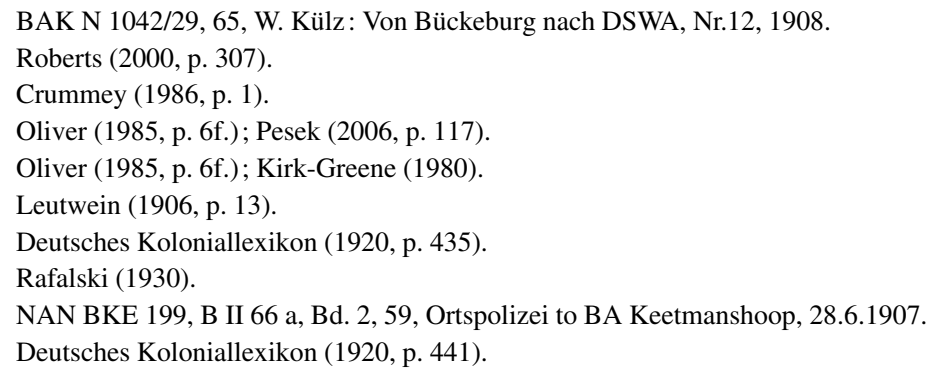


urgent need for forces familiar with the colony's territory, and considering the limited funds available, the colonial administration resorted early on to recruiting Africans. As the inspector of the colonial police, Heinrich Bethe, would later state, their involvement in the formation and up-keep of the colonial state would be "indispensable" ${ }^{37}$.

Without African policemen, police-work in the colony would have been impossible; without the assistance and cooperation of African personnel, the colony could not have functioned in the way it did. Irrespective of whether or not one wants to call their practice "collaboration", it needs to be emphasized that in GSWA the administrators were just as dependent on their African workers, interpreters and "servants" as their French or British counterparts ${ }^{38}$. African policemen were crucial in coping with the every-day police-work in the colony, a fact that was recognized by contemporaries: after all, local Africans knew the colony's terrain. They also spoke the languages of the colony's inhabitants, and were much cheaper than German servicemen. To characterize - or denigrate - these African colonial personnel as "collaborators" may suit an attitude of enmity, as it can be described in the context of European occupation regimes. To use such terminology in the context of late $19^{\text {th }}$ to early $20^{\text {th }}$ century colonial regimes, however, is to ignore the variety of motives that African men had to join the colonial forces ${ }^{39}$.

The early colonial state of GSWA could, and did, count on the cooperation of African men in joining the police and military services. The payment these men received was often better than what farm workers or servants of tradesmen could expect, and they also benefitted from the high social esteem of uniformed men amongst the African communities. Such was their motivation that these men were employed in gunfights; after skirmishes with smugglers, the chief of the borderposts along the Orange River stated in 1897 that he could, "with regard to the native policemen, report only favorably" ${ }^{40}$. He was not alone in this: the 1898 annual report of Angelo Golinelli, the border-post chief's superior and head of the southern district (a man who would also go on to become a high-ranking official in the Imperial colonial office), spoke highly of the 38 men in his "native police-corps". Most of these "brave men" of Namaland had served him for more than two years already ${ }^{41}$.

After the wars against the Ovaherero and Nama (1904-07), "native policemen" were called "police servants", with the ranks of "police sergeant" and "constable" being reserved for Germans. Technically, this distinction was an indicator that the importance of the "police servants", who had no authority towards Europeans, was intended to be curtailed. The situation on the ground, however, remained unchanged. The colonial state was unable to renounce their work: "police servants" still being allowed to carry weapons and ride horses. It was even possible to assign "police servants" to independent patrols against "robbers", without the command of

37 BAB R 1002/2432, Draft: Gouv to all BA and DA, 13.7.1914; cf. Gewald (1999, p. 204f).

38 Osborn (2003, p. 43f.; 32); see Lawrance, Osborn, Roberts (2006).

39 See e.g. Osterhammel (2003, p. 72); Gewald (1999, p. 204f.).

40 BAB R 1001/1489, p.98, "Bericht über das Gefecht bei !Kaudaus (Hamsib-Kluft) gegen die Afrikaner-Hottentotten am 05.07.1897".

41 NAN ZBU 147, A VI a 3, Bd.3, 366f, Annual report Southern District, 97/98, 27.6.1898. 
a German policeman ${ }^{42}$, since "whites" were considered unable to track "native criminals" as African personnel could do ${ }^{43}$. In addition to employing "police servants", the colonial administration also deemed it necessary to enlist other Africans for more short-term uses, such as specific patrols. These temporary recruits were paid, or rewarded 'in kind', once a specific wanted "criminal" had been apprehended ${ }^{44}$.

One final example, relating to the German Colonial Office's 1914 ban on independent "native patrols" in German-East-Africa and the Cameroons, underlines many of the issues explored in both this and the previous section. Upon learning of the ban, the then governor of GSWA, Theodor Seitz, urged the colonial secretary to continue to approve the independent deployment of "police servants" in his territory. At the same time, Seitz warned his regional administrators that Berlin wished to curb the use of independent "native patrols" their everyday experience, colonial officials presumed the indispensability of African personnel in maintaining colonial rule, and that it would prove too difficult to succeed without them. This example also points, once again, to a general problem experienced by colonial administrators. The regulations and ordinances originating in Berlin or Windhoek were often "unenforceable" in the huge swathes of colonial territory; this 'unenforceability' being due to a combination of a lack of resources, funds, personnel and knowledge - as well as due to the indignation of Africans who were simply assumed to be the passive receivers of orders. The African population's notion of colonial (police) power was also often shaped by such limitations, limitations that could barely be overlooked by either coloniser or colonised. The inalienability of African (police) personnel proved to contemporaries the limited power of the colonial state.

\section{COLONIAL POLICING PRACTICES}

\section{Impoverishment, and the "problem" of "robbers" and police patrols}

The targeting of "robbers" and "rustlers" by police patrols, as well as by other measures, certainly point to the most pressing security issue for the administration in GSWA. The cause of such criminal behaviour, however, was largely unrecognized by both colonial administrators and settlers: the impoverishment of the African population through war and expropriations. Cattle and other valuables were lost or confiscated, and other means of income were often insufficient to make a living ${ }^{46}$. Such conscious acceptance of the pauperisation of the majority of Africans in GSWA was a grave burden on the colony's security situation: colonial police work proved this fact on a daily basis.

42 Cf. e.g. NAN ZBU 406, D II d 2, fol.1, p.157-180, 166, 10.10.12; Bd. 2, 40, KdoSchTr to Gouv, 19.4.1913.

43 NAN ZBU 406, D II d 2, Bd.3,141, BA Outjo to Gouv, 31.7.1914; Leutwein (1906, p. 536).

44 NAN ZBU 715, F V o 2, Bd.2, 55, PolSt Großaub report, 25.07.1912; 53, BA Keetmanshoop to Gouv, 23.08.1912.

45 NAN BOM 34, 2, Gouv to BA Omaruru, 05.05.1914.

46 NAN ZBU 694, F V f 1, fol. 1, 199, DA Bethanien to Gouv, 04.01.1908. 
In sections of the territory that would later become GSWA, the stealing of cattle had been a constant feature of $19^{\text {th }}$ century economic and political life ${ }^{47}$. Despite the advent of the colonial administration in the 1880's and 1890's, this facet of local life would continue largely unchecked, as Governor Leutwein deplored in $1901^{48}$. Indeed, even after the wars of 1904-07, the intended European standards of "peace and order" still did not prevail everywhere. The colonial state was forced to constantly send patrols across (at least) the "police zone", in order to "remind" Africans of its presence.

In part the colonial state helped create the problems it was unable to solve. After the wars, many Africans were forced to work on farms: the governor granting few exceptions to a general prohibition on Africans keeping their own cattle. The farm work upon which they were thus forced to rely was often inadequately paid, with forms of payment in kind still proving insufficient to sustain the livelihood of a worker and his family. Some colonial administrators were aware of this situation. An official deplored the meagre daily ration of a farm worker: "one can of maize, barely $3 / 4$ pound, is not enough for a native who works all day long, in particular as he does not receive meat, milk or fat" ${ }^{\prime 9}$. Understandably, workers were forced to supplement their food by various means : by 'poaching', theft, the poisoning of livestock, scavenging for carrion, or by gathering. As the historian H. Bley has stated, "[t]he Africans were always ready to escape into the bush [...] since they might as well starve there as in European employ" ${ }^{50}$. An official remarked that "most of the theft of livestock is committed by keepers of the stock" ${ }^{\text {". }}$. A connection between the poor living conditions endured by workers, including their brutal treatment by farmers, and their subsequent engaging in "criminal behaviour" like cattle theft, or the formation of "robber gangs", was thus comprehensible.

Once a cattle theft or other form of "banditry" was reported to the nearest police station, patrols of up to ten men or more would attempt to follow the tracks. If the police were unable to track larger groups of "bandits", or could not dare to engage them point-blank, the military was called in for assistance. As a result, heavy criticism of the police and their perceived 'inefficiency' was rampant in the colonial press $^{52}$. With the police seemingly unfit to solve the problem, 1912 saw the governor of GSWA decide to further militarise the fight against such criminal behaviour: in future, cases of "banditry" were to be referred directly to the nearest military authorities by the local civil administration ${ }^{53}$. Not all local administrators would follow this requirement though, as some were hesitant to take responsibility for having engaged the military ${ }^{54}$; nevertheless, the brutal actions of the police and their German and African volunteers, as well as the military, are still evident in the colonial police files regarding patrols against such "robbers".

\footnotetext{
See Henrichsen (1997, p. 266f.).

48 BAB R 1001/1491, p. 92, Gouv to Colonial Department, 22.03.1901.

49 NAN ZBU 108, A III e 1, 48, Gouv to BA Windhuk, 23.11.1912.

50 Bley (1996, p. 253).

51 NAN ZBU 158, A VI a 3, Bd.23, 10, Annual report BA Outjo, 1910/11, 10.04. 1911.

$52 \quad$ E.g. Südwestbote $\mathrm{N}^{\circ} 104,30.8 .12$, p. 1; Südwest, 5.11.1912, p. 1.

53 NAN BOM 53, 28, Ordinance to all BA and DA, 22.05.1912; see Gordon (1992, pp. 57-59).

54 NAN ZBU 406, D II d 1, 82, Ordinance to all DA and BA, 13.05.1913; NAN ZBU 406, D II d 2, Bd.2, 210, Tlgr BA Outjo to Gouv, 12.01.1914.
} 
These acts of brutality can, in some way, be understood. Similar to the behaviour that Alf Lüdtke describes the Prussian authorities displayed towards their subjects during the "Vormärz" (the eve of the 1848 German revolution), the colonial state and its authorities considered themselves to be permanently besieged by insurgency and revolt. As a result, the colonial authorities regarded brute force against (potential) insurgents as both 'necessary' and 'justifiable' ${ }^{55}$. Similar to practices in Germany during strikes and other forms of civil unrest, the colonial military remained the last resort for the governorate to ensure internal peace ${ }^{56}$. The distinction between military and police tasks in GSWA was far less clear; a situation similar to those found in British colonial institutions of the time ${ }^{57}$. This problem was reflected in the German colonial military law of 1896, which referred the maintenance "of public order and security" (i.e. police tasks) to the military ${ }^{58}$. Since colonial police and military forces were fulfilling similar functions in maintaining internal security, the colonial administrators of GSWA began to discuss a potential merger of the two security institutions in 1909; an initiative largely intended as a cost cutting measure. However, no decision on the creation of a "Gendarmerie" would be reached until 1915.

The fear of "banditry" and riots thus remained a constant feature of the colonial administration. The slightest 'sign' of "insubordination" had to be recorded. Even correspondence of Africans could be controlled ${ }^{59}$; another example which displays how precarious colonial administrators considered the status quo of "public order and security" in GSWA.

\section{Police and the "native regulations"}

With violence and the pauperisation of the African population, the relation between Africans and GSWA's settler society, including its police force, is to be considered here. Accounts by the affected individuals, i.e. the colony's African population, are almost none existent: sources of African origin have barely found their way into (colonial) archives, and the historiographical tool of oral history is barely available after the passage of 100 years $^{60}$. Those individual accounts that did find their way into the sources, however, suggest that fear of the police prevailed. Indeed, the view held by senior police officials that the "main task" of GSWA's policemen was "to control and oversee the natives" ${ }^{61}$ became a defining aspect of the relations between the colony's police force and its African population.

Shortly after the state of war in GSWA ended on March 31, 1907, three so-called "native regulations" were issued. Regarding the 'control of Africans', the 'carrying of (official) passes' and also the 'labour contracts' between Africans and Europeans, the purpose of these regulations was, according to some scholarship, the "total

\footnotetext{
55 See Lüdtke (1982); Lindenberger (1995, p. 204).

56 Kutz (2006, p. 32); Wehler (1970, pp. 65-78, 1995, p. 1127).

57 Hills $(2000$, p. 29).

58 Tiebel (2008, p. 150).

59 NAN ZBU 2053, W III p 1, p.3, Postdirector Thomas to all heads of post offices, 13.01.1909; ibid., p.1, Postdirector Thomas to Hintrager, 16.01.1909.

60 See e.g. Henrichsen (1997, p. 44).

6126 NAN BOM 53, 28, DA Omaruru to Police Station Omaruru, 26.1.1912.
} 
control" of African societies ${ }^{62}$. The use of such terminology in a colonial context evokes a comparison with the totalitarianism of later regimes. Although some historians certainly describe a path "from Africa to Auschwitz"63, others, also with a view on the colonial "weakness" 'in the field', state "that the significance of colonialism for the phenomenon of National Socialist tyranny [does] not deserve such heavy emphasis" "64. Indeed, such 'comparisons' (if not equations) serve more to conceal, rather than analyse, the actual power and assertiveness of the colonial state before World War I.

This statement is not meant to dispute the fact that these regulations deeply affected the every-day life of Africans in GSWA however. They limited both freedom of movement and choices of employment. By almost prohibiting the ownership of cattle, they hindered the economic development of Africans and also served to destroy a cultural foundation of the Ovaherero. The colonial state also pretended to be able to control their entering into voluntary labour contracts with Europeans, as well as the movement of Africans. Section 9 of the "control regulation" stipulated that Africans had to live in specific, and police supervised, "native compounds" (Werften). Governor Friedrich v. Lindequist would set out the principles regarding the execution of this regulation, emphasising that "any interference in internal affairs and disputes, in domestic family- and civil law shall be avoided, unless the natives themselves ask for a decision" ${ }^{65}$. Giving advice to the effect that local problems should be left to the "natives" was common practise among the colonial administrators of all empires. This principle of "non-interference" was not only based on convenience and practicability, but also on the confession that "officials did not fully control or understand the conflicts and contests that took place within their colonial empires" $" 66$.

The implementation and control of these three "native regulations" was, mainly, left to policemen. They experienced problems in executing the (few) rights that Africans did have under these new regulations, often finding them to be unenforceable. Unsurprisingly, conflict, fear and punishment came to dominate the relations between Africans and police personnel, known as "opolisei" in Otjiherero ${ }^{67}$. As a Herero-woman from Karibib would complain in a letter: "At our place the police are very vicious" ${ }^{\prime \prime 8}$. In view of this hostile perception, the head of the regional administration of Omaruru gave a frank assessment of the relations between Africans and policemen: "Most often the native learns about the police only as a punishing authority, and therefore he does not properly trust it"69. In GSWA, the African population's negative stance towards Germans was largely informed by their experience of the wars (1904-1907), as well as the brutal treatment continually meted out to them by their employers. As banditry and other forms of unruliness proved, many

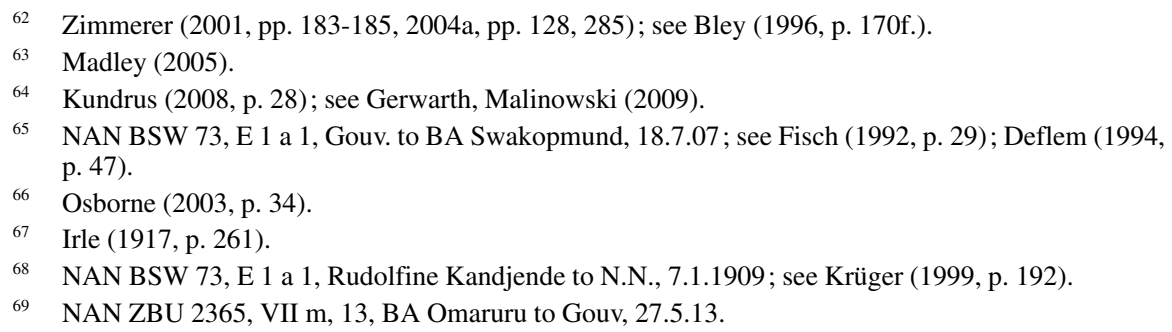


Africans did not readily accept the German claim to power. Colonial administrators were thus all too well aware of the fragility of their ruling structure, and consequently permanently feared potential uprisings. Provocations were to be avoided. All colonial officials were, by internal rules, obliged to have a "good relationship" with Africans. Indeed, it was considered a "prerequisite that the native [be] treated benevolently and with self-restraint", and that "attacks and unjustified roughness, which are often based only on ignorance of the language and customs of the natives, [should] be avoided at all costs" ${ }^{\text {, }}$. The following chapter will examine the attempts at resolving this ignorance, as well as the wider questions of communication and language that leading colonial officials correctly ascertained to be central to the upholding of colonial rule.

\section{LANGUAGES USED BETWEEN AFRICANS AND GERMAN POLICEMEN}

Colonial encounters were not first and foremost a matter of physical violence colonial military means were simply too weak for this. Negotiations regarding the balances of power were far more common, often with both sides harbouring fundamental misconceptions of the other: in the context of GSWA, pertinent examples being provided by the "negotiations' relating to the "protection treaties" of the 1880 s, as well as the subsequent "signing' of these agreements by "crosses". Although sign language and interpreters necessarily represented the first elements of such encounters, other kinds of non-verbal communication could also be employed. Either by theatrical poses in splendid uniforms or the presentation of European (arms) technology in intimidating ways, the message of 'white supremacy' and colonial order could be communicated by a number of means ${ }^{71}$.

These means would reach their limits in colonial everyday life. Even after 1900, when the power to exert control over people and land in GSWA was passing more and more to the Germans, language(s) remained a 'front' that could still be used by Africans to defend and promote their own interests. Indeed, languages remained a place of retreat for African societies, a place not easily conquerable by colonisers. To try to contain this 'space', the colonial authorities of GSWA employed two methods, the first of which being to school African interpreters in German. Known as "German for Africans", this step was to remain controversial among colonizers, some of whom fearing that 'civilization' might have some kind of 'distorting influence' on Africans ${ }^{72}$. The second method, aimed at reducing the colonial state's linguistic dependency on Africans, was to encourage German colonists to learn an African language. Although some colonists did indeed try to do this, both their undertaking and their methods have been paid little attention by researchers. As a result, the following chapter can only serve as a cursory approach to the topic.

70 BAB R 1001/9098, 1115, Bestimmungen für die Landesbeamten... in den Schutzgebieten, 2/06.

71 Trotha (1994, p. 38); Pesek (2005, p. 263f.).

72 Kundrus (2003, p. 189f.); Osterhammel (2003, p. 107); Dietrich (2007, p. 187); Südwestbote, 11. Jg No 34, 20.3.1914, p. 1. 


\section{The inadequacy of interpreters for colonial purposes and the necessity of African language skills}

Decades before a German administration was established in the area, the missionary Carl Hugo Hahn warned his brethren about the use of interpreters. Demanding that other missionaries learnt African languages, Hahn spoke of African languages as a "giant" that was "to be mastered" . Although mastering the "giants" was never a prerequisite for employment in the German colonial service, officials in both Berlin and GSWA recognized the advantages that in-depth language knowledge, and thus the information and decisions that could be arrived at as a result of it, had to offer. The German Colonial Society (Deutsche Kolonialgesellschaft - DKG) was convinced that "all reasoning argues against the constant employment of often evil-minded and, more often [...,] unreliable mediators", desiring instead for colonial officials to be able to communicate directly as soon as possible ${ }^{74}$. Having expressed a similar view a few years earlier ${ }^{75}$, Colonial Director Paul Kayser even intended to offer rewards to those who learnt "native languages". Indeed, the DKG explicitly pointed to the experience of the head of administration in GSWA, Curt v. Francois, who had stated that officials could only ensure they weren't being tricked by "native chiefs" through a good command of their language ${ }^{76}$.

When asked for his opinion on the language skills of his officials in 1896, the head of the Windhoek district, v. Lindequist, stated that "the learning of native languages is very important for public servants and officers". He welcomed good knowledge of the "Dutch dialect", i.e. Cape-Dutch (a language also used for correspondence), and claimed that most of his officials had already learnt to write and speak in this language ${ }^{77}$. Its usefulness, in comparison to the difficult Nama/Damara-language, was clear - as Lindequist's colleague in Keetmanshoop, Gustav Duft, emphasized: "there is barely a werft in Namaland where one is not able to communicate in [Cape-] Dutch"78.

Irrespective of such flattering assessment: The denser the colonial administration became, the more the lacking foreign language skills of both Europeans and Africans became evident. The linguistic ignorance of colonial officials was compounded by the fact that most of their translators were judged to have inadequate knowledge of the language they were translating. This issue became a hindrance of growing importance ${ }^{79}$ and the colonial language problems did not go unnoticed in the parliament, or in the higher echelons of the colonial administration. Pointing to the lack of language skills, in 1906 the representative Schwarze demanded: "that [...] [colonial] officials [...] must learn the native language. It is a major shortcom-

Carl H. Hahn, 22.10.1866, in Sundermeier (1962, p. 191); Goldblatt (1971, pp. 194-196).

BAB R 8023/880, fol.1, 19, DKG to Colonial Department, 20.9.1894.

NAN ZBU 2019, W I b 1, Bd.1, 21, Colonial Department to v. Francois, 27.2.1892.

76 BAB R 8023/880, fol.1, 14, Bericht über die Sitzung des Vorstands DKG, 16.5.1894.

77 NAN ZBU 249, B I qu 1, 7, BHpt Windhoek [v. Lindequist] to Gouv, 25.1.1896; ibid., 17, StS RKA to Gouv, 12.4.1913.

78 NAN ZBU 249, B I qu 1, 11, BHpt Keetmanshoop to Gouv, 10.2.1896.

79 Osterhammel (2003. p. 106); AELCRN, C I 1.2, Protokollbuch der Konferenzen im Namalande, 357, 14.9.1902, 332, 19.9.1900; AELCRN, C I 1.40, 8, Diehl to Leutwein, 1.5.1901; see Zimmerer (2004a, p. 245f.). 
ing of our [colonial] officials that they are unable to communicate directly with the people, but instead rely on interpreters" ${ }^{" 80}$. By this point, it had been over ten years since Colonial Director Paul Kayser and others had first emphasised the importance of language skills for colonial officials, a period of time that had seen the situation barely improve. As can be seen from an internal memorandum of 1911, future progress on this matter would continue to be slow. The author of the memorandum, Vice-governor of GSWA Oskar Hintrager, disapproved of the lacking language skills of his German and African colonial personnel. He considered the lack of qualified interpreters a serious setback for the "orderly [running of the] native judicial system", asserting that the "words of the official as well as of the natives are often disfigured by the interpreter". Demanding that this be remedied by increasing the German language instruction that African children received in missionary schools, Hintrager also expected that German officials in GSWA "pay particular attention to the learning of native languages"

Despite Hintrager's unambiguous words, Governor Theodor Seitz would also find himself dissatisfied with the handling of the "native judicial system" two years later. After having read some "criminal files", Seitz had learnt, "with regret", that the "interrogations of natives [by German policemen]... have been executed in a mostly insufficient manner". This had even happened in cases involving the death penalty. Similarly to Hintrager, the Governor deemed the inadequacy of interpreters to be the main difficulty for the administration of the "native judicial system". Seitz condemned the common practice of, on a "case-by-case basis", calling in "a native" (usually an African policeman) whose language skills had never been examined to serve as an interpreter: "no official can hold responsible office of a native-judge without being able to communicate flawlessly with the native" 82 .

According to these sources, communication problems prevailed in the interactions between the colonial officials of GSWA and the local African populace. There was also, however, a recognizable policy that demanded colonial officials learn the local African languages, indicating a preference for language learning by officials over a continued reliance on African interpreters. This preference was based on several insights. Most of the administrators had, at some point, experienced insufficiently skilled interpreters; many of them arbitrarily summoned individuals. Colonial administrators were aware of the uncertainty resulting from such practices, and also knew that a 'just native policy' (as propagated by the colonial administration) would not be achieved in this way. Moreover, it seemed to be only a matter of time until a tragic occurrence, for instance a misjudgement based on incorrect translations, would become known to the wider public - something that may have led to deleterious debates in parliament. Governor Seitz's hints at the use of inadequate translations in cases where the death penalty could have been imposed alluded to this risk: this language policy was therefore also an expression of self-protection.

In addition to this, the strategic advantage offered by language knowledge must also be taken into consideration. Similar to the situation in British colonies, where the early $19^{\text {th }}$ century policy of encouraging the native population to learn English had already been abandoned, the administration of GSWA was faced with the

\footnotetext{
80 SBRT, Bd. 216, 11. Leg.Per. 2. Session 1905/06, 67. Session 16.3.1906, pp. 2058-2060.

81 NAN BSW 73, E 1 a 1, Gouv to BA Swakopmund, 30.6.1911.

82 NAN ZBU 249, B I qu 3, 9, Ordinance to all BA and DA, 19.12.1913; cf. Meyer (1905, p. 538).
} 
question of whether the spread of the German language was useful or detrimental to colonial purposes. Seemingly, there was a lot to be said in favour of avoiding any such potential 'risks'. The acknowledgement and appreciation of local elites, on the basis of their good command of German, could have awakened "unfulfillable wishes" among them ${ }^{83}$. Furthermore, the dependency on these elites as middlemen between colonial administrators and 'ordinary' Africans was to be avoided, similar to concerns in French Africa ${ }^{84}$. There was thus no other option but to develop the competencies of German officials in African languages.

\section{German officials as African language students}

Admonitions to learn African languages reached policemen and other German colonial officials from both Windhoek and Berlin. Demanding that his officials acquire language skills was a principle of Colonial Secretary Wilhelm Solf, who had earned a doctorate in oriental languages before studying law. During a visit to GSWA in 1912, Solf encountered problems as a result of misunderstandings between himself and his African servant, commenting: "A true South-westerner would have punched his face. I only concluded that the people here figure that the natives speak German". Solf expected better from his officials. As Paul Kayser had done twenty years before, in April 1913 he reminded colonial officials to consider "the acquiring of native languages to be among [their] duties". The governor in Windhoek responded that "until now[,] only very few officials [from the governorate] undertook the efforts to learn a native language $"{ }^{\prime 85}$. Contrary to the officials in the governorate $^{86}$, policemen working in the stations and regional offices across GSWA were more open to learning African languages. This is comprehensible; in their offices and 'on the beat', direct contact and thus communication with the African populace was a daily necessity. Indeed, policemen were well aware that having at least some language skills was an indisputable advantage. Sergeant Rüdiger, after returning from a patrol in Kaokoveld, indicated one of the possible benefits of learning a local language: "the Ovatjimba are much more trusting if they encounter someone who speaks their language $" 87$. Furthermore, and contrary to the situation in colonial settlements like Windhoek, missionaries capable of translating were generally unavailable either during patrols or in most of the police stations in the farm areas. Understandably then, section 24 of the "central internal regulation for policemen" stipulated that the "learning of the natives' language is very desirable. By exchanging their ideas with each other, police officials will teach one another" ${ }^{\prime 88}$. The learning of African languages was, however, never a formal requirement for policemen. Material support for those policemen making efforts to learn a local language, in the form of either courses or teaching materials, was largely not forthcoming. Rather than supply these

83 Steinmetz (2007, p. 352); see Kundrus, (2003, p. 189).

${ }_{84}$ Steinbach (2005, p. 164; p. 168); cf. Eckert (2005, p. 271); Osborne (2003, p. 30).

85 NAN ZBU 249, B I qu 1, 18, RKA to Gouv, 12.4.13; 19, Gouv to RKA, 14.6.1913: cf. Steinmetz (2007, p. 498).

86 NAN ZBU 249, B I qu 2, 6, Gouv to Missionar Müller, 15.7.14; AELCRN, V 37, GemeindeChronik, p. 55, Meier to Gouv, 30.6.1914.

87 NAN BOU 1, B 10 q, 187, Police Station Zessfontein to BA Outjo, 6.6.1911; cf. Gewald (1999, p. 12).

88 NAN BWI 155, L 2 b, fol.1, Attachment: Gouv to BA Windhuk, 25.9.1907. 
things, it was assumed by their superiors that policemen would simply recognize the necessity of African language skills. At least in some instances, this assumption would prove correct.

After the 1911 reminder of Vice-governor Hintrager that "officials [should] pay particular attention to the learning of native languages", the heads of GSWA's regional administrations were obliged to report on the capabilities of their staff. From examining these reports, it becomes clear that some policemen had indeed learnt a degree of their local African language, knowledge that could be useful in communicating colonial order. Berengar v. Zastrow, head of the Grootfontein district, stated that his policemen had attained sufficient knowledge of Otjiherero to be able to "know the commonly used words". Whereas some taunted the Nama/ Damara population for their "animal-like" clicking language ${ }^{89}$, the head of Gibeon district named four policemen who "study the native [Nama/Damara] language", and pointed to the challenges of learning it without a teacher. His colleague from Bethanien reported that his "constable knows a few words of Namaqua", but was forced to quit a language course run by a local missionary due to time constraints. In addition, six policemen from Karibib had also tried to learn the Otjiherero or Nama/Damara language. The head of Maltahöhe-district, Seydel, would in contrast paint a somewhat less positive picture, commenting: "The few policemen in this district have neither sufficient talent nor time to learn the Namaqua-language." The general busyness of policeman was also noted by several other regional administrators, who claimed that, "due to a lack of time nobody was able yet to learn a native language" 90 .

During their three-month leave to Germany, officials bound for the northern part of GSWA were requested by the Colonial Office to study one of the Ovambolanguages at the Seminar für Orientalische Sprachen in Berlin. This move was supported by the governorate of GSWA, in particular for policemen on duty in Okaukuejo, Outjo, Namutoni and the diamond fields near Lüderitzbucht, where hundreds of Ovambo migrant workers lived. The policemen themselves also responded with some enthusiasm - 1910 saw 16 policemen indicate their availability for courses during their leave $\mathrm{e}^{91}$. This interest would continue, even to the point where the head of the Lüderitzbucht district requested, in 1914, that the governorate finance a missionary-run Oshivambo course, for which "up to now 12 officials have already registered" ${ }^{92}$. The results of such courses, or indeed those of other more informal ways of learning, are difficult to assess however. In the early $20^{\text {th }}$ century, the European analysis and didactical preparation of African languages was still rudimentary. The adequate translation of many terms remained "a difficult business, especially since the Bantu languages [among them Otjiherero and Oshivambo] were not nearly so simple as some claimed"93.

\footnotetext{
89 Steinmetz (2007, p. 154).

90 NAN ZBU 249, B I qu 4, 4, BA Outjo to Gouv, 14.11.1911, 8, BA Grootfontein to Gouv, 15.12.11, 5, BA Gibeon to Gouv, 5.12.1911; 3, DA Bethanien to Gouv, 28.11.11, 12, BA Karibib to Gouv, 10.1.12, 6, DA Maltahöhe to Gouv, 1.12.1911, 9, DA Gobabis to Gouv, 18.12.1911.

91 BAB R 1002/2549, 94, RKA to Gouv, 28.2.10, 96, ILP to PolDep, 25.5.10, 92, ILP to Gouv, 22.11.10.

92 NAN ZBU 249, B I qu 3, 4, BA L'bucht to Gouv, 15.5.1914. Lüderitzbuchter Zeitung, 6. Jg. \# 8, 20.2.1914, p. 2.

93 Worger (2001, p. 419).
} 
Nevertheless, through the examination of sources compiled by policemen, it can be assumed that communication with the African population was still possible. An example of such communication is detailed by the inspection officer Hildebrand, head of the police depot Waterberg, who explained in 1909 that: "From time to time, the natives, passing Waterberg, are turning to the police office or to me in order to receive news from family members" 94 . It was thus possible for Africans to contact policemen directly, and for both sides to find the means to tolerably understand each other - at least in some cases. According to Hans Rafalski, first assistant to the police inspector in Windhoek, policemen were indeed able to just about communicate in the native languages ${ }^{95}$. Furthermore, numerous communication exchanges are detailed in the reports of patrolling policemen, and contain statements such as: "according to the woman..."; (Weib) "... as has been confirmed to me by the woman"; (Weib) and "The man told me..." . Although discourse is evident, the sources leave open the question as to what language was actually used in them: whether during such encounters German prevailed over Otjiherero, Nama/Damara or Oshivambo respectively, or indeed whether both sides used Cape-Dutch as their preferred means of communication ${ }^{97}$.

Cape-Dutch was not only spoken by the Boer population of GSWA; it served as the lingua franca in Nama- and Hereroland. Even if knowledge of the Otjiherero, Nama/Damara or Oshivambo languages remained limited among policemen, many of them were able to speak Cape-Dutch, which was easier to learn for Germans. Vice-governor Hintrager spoke the language well ${ }^{98}$ (he had fought with the Boers in the South African War), and over the years several policemen achieved similar levels of fluency. Indeed, in the southern-most district of Warmbad, knowledge of Cape-Dutch was considered a "necessity" for policemen. Wider concerns could still temper its usage however: although the head of this district believed that all his policemen could "speak the language well", he feared for the "Germanness" of the colony and so preemptively ordered his officials to communicate "with the Boers in German" 99 .

Along with Cape-Dutch and other African languages, English also formed part of the linguistic landscape of non-German languages that characterized GSWA; similarly to Cape-Dutch, it had also been widespread in the area since pre-colonial times. Despite their reservations about the influence of English, the German administration had to take into account the economic and political dominance of the Cape Colony in southern Africa. As a result, English remained of importance in GSWA, and certainly also for its policemen. Due to their close proximity to the border with British-ruled Walvis Bay, 11 police sergeants stationed in Swakopmund requested English lessons in 1907 - a request supported by their superior Hugo Blumhagen ${ }^{100}$.

94 NAN ZBU 2053, W III p 1, 14, PolDep Waterberg to ILP, 18.2.1909.

95 Rafalski (1930, p. 30).

96 NAN ZBU 406, D II d 2, Bd.2, 91, 93, Patrouillenbericht des Polizeiwachtmeisters Eschen, 8.8.1913.

97 Nöckler (1963, p. 35).

98 BAB R 1002/783, 10, AAKolA to Gouv, 5.7.1905.

99 NAN ZBU 747, G I b 1, 129, Gouv. to ILP, 30.6.1913; ibid., 140, BA Warmbad to Gouv with remark, 22.7.1913; see Walgenbach (2005, p. 213).

100 BAB R 1002/2549, 66, BA Swakopmund to Gouv, 26.12.1907. 
They were not alone: policemen in other areas of GSWA, such as Windhoek and Bethanien in the colony's south, would also receive tuition in English ${ }^{101}$.

Life in GSWA, with its mixture of cultures and languages (and where rudimentary knowledge of at least some of these was a distinct advantage), therefore tended towards the multilingual. As a result of this however, concerns arose in both Germany and the colony regarding the "purity" of the German language there. Relating to more general anxieties about the "Germanness" of Germans in GSWA, colonial enthusiasts recognised an alleged "passive racial defilement" ("kaffrization") of a number of settlers: "similar to the English phrase 'gone native', evoke[ing] hapless German men, sexually and symbolically contaminated by native women and culture" -including the language ${ }^{102}$. Such discourses though, as well as the symbolic meaning of the German language in the colonies, have already been repeatedly analysed by historians ${ }^{103}$. When considering the fact that some contemporaries feared for the "purity" of German culture and language in the colony, one should however not ignore that the learning of African languages by officials - and in particular policemen - was actively promoted by the German colonial administration.

Nevertheless, German colonial officials only enjoyed modest success in their attempts to learn African languages, due in part to both the reluctance of individuals and a lack of material support. Indeed, the level of proficiency that these men gained in the various languages, with or without the aid of formal training, remains as yet unknown. What is noteworthy, however, is that - according to their superiors around ten percent of colonial policemen occupied themselves with learning Nama, Otjiherero, Oshindonga, Oshikuanjama and/or Cape-Dutch. Despite these efforts though, the Cape-Dutch and German language skills of GSWA's African population remained predominantly important in facilitating communication between colonizers and the colonized; thus, despite all the criticism, African interpreters would still remain indispensable for colonial purposes.

\section{CONCLUSION}

Looking at the short history of the colonial police force of GSWA (1894-1915), it can be concluded that its creation (as a body distinct from the army) was most of all a symbol of 'normalisation'. GSWA was, after all, intended to become a settler colony, similar to British South Africa; as a result, the growing number of settlers in the colony could not be policed by the military, given the custom in Imperial Germany to only use soldiers for police tasks during riots or other emergencies ${ }^{104}$. This 'normalisation' would not go as smoothly as desired however, being hampered by both organisational and financial difficulties, as well as by the unruliness of both the local African populace and the settlers themselves. Such difficulties also led German contemporaries to constantly question the efficiency of the police force in

101 NAN BWI 160, L 2 m, 23, BA Windhuk: Stundenplan 1913; NAN ZBU 249, B I qu 2, 2a, DA Bethanien to Gouv, 31.7.1911, 2b, Gouv to BA Bethanien, 19.8.1911; Walgenbach (2005, p. 214).

102 O’Donnel (2005, p. 44); see Ahlhorn (1926, p. 340).

103 Axter (2005); Mühleisen (2005, pp. 30-48); Kundrus, (2003, p. 189f.); Walgenbach (2005, pp. 205; $248 ; 212-215)$; Dietrich (2007, p. 188).

104 See Johansen (2005). 
GSWA, especially given the dissatisfying relation between the costs incurred and the benefits gained. Amongst other issues, the police seemed unable to solve the problem of "banditry", as their continued calls for military assistance attested. Since costs rose as a result, the German parliament insisted on further reductions to the police. Indeed, the planned merger of the two colonial security institutions in 1915 was a logical conclusion, considering the similarity of their chief tasks: to control - and subdue if necessary - the African population. Although the outbreak of World War I prevented this institutional change, 1915 or 1916 may still have been the final year of a distinct police force in GSWA, even without the South African conquest. The attempts to 'normalise' the colonial state, according to European patterns, had thus failed.

The involvement of African personnel in GSWA's police force could not prevent this failure. Nevertheless, Africans proved to be indispensable to the police throughout the period of German colonial rule. Contrary to the wishes of some in the German colonial administration, the German officials' dependency on their skills and knowledge could not be diminished - African policemen remained as much a part of the German colonial state as they were in any other.

Knowledge of language was essential for colonial purposes, however for most of the time only African interpreters had sufficient knowledge of all the languages involved. Police practices (such as regulating, punishing, informing and recording) were dependent, one way or another, on communication with the local population. Likewise, German administrators were dependent on their African personnel in the reverse direction: these "colonial rulers constantly [trying] to hear what their subjects were saying through actions, words and symbols"105. Without Africans, and their knowledge of the German language, they were unable to do so.

In the colonial context, the ability to speak and listen became increasingly important as the regulatory framework developed and grew denser. Unsurprisingly, colonial administrators considered their continued dependence on African interpreters as a defect in their otherwise supposedly constantly strengthened dominance of the local population. Although the wider administration requested more German officials learn an African language, these efforts showed only meagre results until the end of German rule in GSWA. Policemen, regularly 'on the beat' and faced with the difficulties of (mis)communication with the African populace, were understandably more open to learning an African language than other administrators. No concerted policy was ever implemented in this regard however, and apart from the occasional reminders of superiors to improve one's language skills, most of the attempts to do so were left to the colonial policemen's own initiative.

The assumption of officials that "roughness [... is] often based only on ignorance of language and customs of the natives" 106 suggests that it was recognized that, by better understanding Africans, brutalities and other forms of conflict could have been avoided. The question as to what policy for everyday colonial practices could have resulted from such a recognition, however, does not necessarily lead to the answer of a "more moderate approach" 107 The incomprehensibility of their language was one of the 'retreat areas' for Africans; had this area been 'disclosed', colonial

\footnotetext{
105 Dedering (2006, p. 276).

106 BAB R 1001/9098, 1115, Bestimmungen für die Landesbeamten, 2/1906.

107 Steinmetz (2007, p. 467; p. 498).
} 
administrators could have used it to further strengthen their regime. More research is thus needed into not only the question of 'what' was spoken and listened to in encounters between colonial policemen and the African population, but also 'how' this was achieved and to what end.

Jakob Zollmann Wissenschaftszentrum Berlin Reichpietschüfer 50 10785 Berlin jzollmann@web.de

\section{SOURCES}

\section{Primary Sources}

Bundesarchiv Berlin (BAB)

BAB R 1002/2432; R 1001/1489; R 1001/1491; R 1001/9098; R 8023/880; R 1001/9330; R 3001/5251; R 1002/47; R 1002/2549; R 1002/783; R 3001/5255; R 8023/890.

Bundesarchiv Koblenz (BAK)

BAK N 1037/9; N 1042/29; N 1053/36.

National Archives of Namibia (NAN)

NAN ZBU 249, B I qu 1; B I qu 2; B I qu 3; B I qu 4; BKE 199, B II 66 a, Bd. 1; Bd. 2; ZBU 147, A VI a 3, Bd.3; ZBU 406, D II d 2, Bd.1; Bd.2; Bd.3; ZBU 715, F V o 2, Bd.2; ZBU 158, A VI a 3, Bd.23; ZBU 108, A III e 1; BOM 34, 2; BOM 53, 28 ; ZBU 406, D II d 1; BSW 73, E 1 a 1; BSW 73, E 1 a 1; ZBU 2365, VII m; ZBU 2019, W I b 1, Bd.1; GWI 760, Gen VIII 9; EKW 1, F V k 3; ZBU 148, A VI a 3, Bd.5; BSW 73, E 1 a 1; ZBU 2053, W III p 2; ZBU 2019, W I b 1, Bd.2; ZBU 2053, W III p 1; BOU 1, B 10 q; BWI 155, L 2 b; ZBU 747, G I b 1; BWI 160, L 2 m.

Archives of the Evangelical Lutheran Church in the Republic of Namibia (AELCRN) AELCRN, C I 1.3; C I 1.2; C I 1.40; C II.1.13.

\section{Printed Sources}

Büttner, C.G., Vorwort, in Kroenlein, J.G., Wortschatz der Khoi-Khoin (Namaqua-Hottentotten), Berlin, Heymann 1889.

Deutsches Koloniallexikon, Vol. 1, Article: Deutsch-Südwestafrika, Leipzig, Quelle \& Meyer, 1920, pp. 410-445.

Florack, F., Die Schutzgebiete. Ihre Organisation in Verfassung und Verwaltung, Tübingen, Mohr, 1905.

Gerstmeyer, J., Köbner, O. (Eds.), Die Deutsche Kolonialgesetzgebung. Sammlung der auf die deutschen Schutzgebiete bezüglichen Gesetze, Verordnungen, Erlasse und internationalen Vereinbarungen, Vol. 1.1892-13.1909, Berlin, Mittler Verlag, 1893-1910.

Irle, J., Deutsch-Herero-Wörterbuch, Hamburg, Friederichsen, 1917.

Meyer, F., Wirtschaft und Recht der Herero, Jahrbuch der internationalen Vereinigung für vergleichende Rechtswissenschaft und Volkswirtschaftslehre, 1905, 8, pp. 439-539.

Leutwein, T., Elf Jahre Gouverneur in Deutsch-Südwestafrika, Berlin, Mittler \& Sohn, 1906.

Passarge, S., Südafrika. Eine Landes-, Volks- und Wirtschaftskunde, Leipzig, Quelle \& Meyer, 1908. 


\section{Secondary Literature}

Ahlhorn, W., Die Sprache von Deutsch-Südwest, in Zache, H. (ed.), Die deutschen Kolonien in Wort und Bild, Berlin, Matrixverlag1926 [2004], p. 340.

Axter, F., Die Angst vor dem Verkaffern-Politiken der Reinigung im deutschen Kolonialismus, WerkstattGeschichte, 2005, 39, pp. 39-53.

Aydelotte, W., Bismarck and British Colonial Policy. South West Africa 1883-1885, London, Greenwood Press 1970 [1937].

Barth B., Osterhammel J. (eds.), Zvilisierungsmissionen. Imperiale Weltverbesserung seit dem 18. Jahrhundert, Konstanz, UvK, 2005.

Betts, R.F., Methods and institutions of european domination, in UNESCO General History of Africa, Bd. VII., Boahen, A. (ed.), Afrika under Colonial Domination 1880-1935, Berkeley, James Currey, 1985, pp. 312-331.

Blackbourn, D., Das Kaiserreich transnational, in Conrad, S., Osterhammel, J. (eds.), Das Kaiserreich transnational. Deutschland in der Welt 1871-1914, Göttingen, Vandenhoeck \& Ruprecht, 2004, pp. 302-324.

Bley, H., Namibia under German rule, Münster, Lit 1996 [1968].

Canis, K., Bismarcks Aussenpolitik 1870 bis 1890. Aufstieg und Gefährdung, Paderborn, Schöningh, 2004.

Chikeka, C.O., European Hegemony and African Resistance 1880-1990, Lewiston, Ewin MellenPress, 2004.

Crummey, D., Introduction. «The great beast», in Crummey, D. (ed.), Banditry, Rebellion and Social Protest in Africa, London, Heinemann Educational Books, 1986, pp. 1-29.

Dedering, T., War and mobility the borderlands of South Western Africa in the early twentieth century, International Journal of African Historical Studies, 2006, pp. 275-294.

Deflem, M., Law Enforcement in British Colonial Africa. A Comparative Analysis of Imperial Policing in Nyasaland, the Gold Coast, and Kenya, Police Studies, 1994, 17, pp. 4568.

Dietrich, A., «Weiße Weiblichkeiten». Konstruktionen von «Rasse» und Geschlecht im deutschen Kolonialismus, Bielefeld, Transcript, 2007.

Eckert, A., Die Verheißungen der Bürokratie. Verwaltung als Zivilsierungsagentur im kolonialen Westafrika“, in Barth, B., Osterhammel, J. (eds.), Zvilisierungsmissionen. Imperiale Weltverbesserung seit dem 18. Jahrhundert, Konstanz, UvK, 2005, pp. 269-283.

Eckl, A., The Herero genocide of 1904. Source-critical and methodological considerations, Journal of Namibian Studies, 2008, 3, pp. 31-61.

Fisch, J., Law as a Means and as an End: Some Remarks on the Function of European and non-European Law in the Process of European Expansion, in Mommsen, W.J., de Moor, J.A. (Eds), European Expansion and Law. The Encounter of European and Indigenous Law in $19^{\text {th }}$ and $20^{\text {th }}$-Century Africa and Asia, Oxford, Berg, 1992, 15-38.

Gann, L. H., Duignan, P., The Rulers of German Africa 1884-1914, Palo Alto, Stanford University Press, 1977.

Gerwarth, R., Malinowski, St., Hannah Arendt's Ghosts. Reflections on the Disputable Path from Windhoek to Auschwitz, Central Euopean History, 2009, 42, pp. 279-300.

Gewald, J.B., Herero heroes. A socio-political history of the Herero of Namibia, 1890-1923, Oxford, James Currey, 1999.

Gewald, J. B., Review of Emmett, T., Popular Resistance, 1999, Journal of African History, 2001, 42, p. 157.

Goldblatt, I., History of South West Africa from the beginning of the nineteenth century, Cape Town, Juta,1971. 
Grohmann, M., Exotische Verfassung. Die Kompetenzen des Reichstags für die deutschen Kolonien in Gesetzgebung und Staatsrechtswissenschaft des Kaiserreichs (1884-1914), Tübingen, Mohr Siebeck, 2001.

Harding, L., Geschichte Afrikas im 19. und 20. Jahrhundert, München, Oldenbourg, 2006.

Helbig, L., Der koloniale Frühfaschismus, in Mbumba, N., Patemann, H., Katjivena, U. (Eds.), Ein Land eine Zukunft. Namibia auf dem Weg in die Unabhängigkeit, Wuppertal, Peter Hammer Verlag, 1988, pp. 102-118.

Henrichsen, D., Herrschaft und Identifikation im vorkolonialen Zentralnamibia. Das Hereround Damaraland im 19. Jahrhundert, (unpubl.) Diss.phil., Hamburg, 1997.

Henrichsen, D., Iss Worte, in Marfaing, L., Reinwald, B. (eds.), Afrikanische Beziehungen, Netzwerke und Räume, Münster, Lit, 2001.

Herbst, J., States and Power in Africa, Princeton, Princeton University Press, 2000.

Hills, A., Policing Africa. Internal Security and the Limits of Liberalization, Boulder, 2000.

Huber, E.-R., Deutsche Verfassungsgeschichte, Stuttgart, Kohlhammer, 1986, Vol. IV.

Johansen, A., Soldiers as Police. The French and Prussian Armies and the Policing of Popular Protest, 1889-1914, Aldershot, Ashgate, 2005.

Kaulich, U., Geschichte der Kolonie Deutsch-Südwestafrika 1884-1915, Frankfurt/M., Kaulich, 2001.

Kirk-Greene, A., The thin white line. The size of the British colonial service in Africa, African Affairs, 1980, 79, pp. 25-44.

Koskenniemi, M., The Gentle Civilizer of Nations. The Rise and Fall of International Law 1870-1960, Cambridge, Cambridge University Press, 2000.

Krüger, G., 'Civilisation is the state of living and of progressiveness' - Zur Bedeutung von Schriftlichkeit in Südafrika um die Jahrhundertwende, in Rothermund, D. (ed.), Aneignung und Selbstbehauptung. Antworten auf die europäische Expansion, München, Oldenbourg, 1999a, pp. 217-234.

Krüger, G., Kriegsbewältigung und Geschichtsbewußtsein. Realität, Deutung und Verarbeitung des deutschen Kolonialkriegs in Namibia 1904 bis 1907, Göttingen, Vandenhoeck \& Ruprecht, 1999b.

Krüger, G., Schrift-Macht-Alltag. Lesen und Schreiben im kolonialen Südafrika, Köln, Böhlau, 2008.

Kundrus, B., Continuities, parallels, receptions. Reflections on the 'colonization' of National Socialism, Journal of Namibian Studies, 2008, 4, pp. 25-46.

Kundrus, B., Moderne Imperialisten. Das Kaiserreich im Spiegel seiner Kolonien, Köln, Böhlau, 2003.

Kutz, M., Deutsche Soldaten. Eine Kultur und Mentalitätsgeschichte, Darmstadt, Wissenschaftliche Buchgesellschaft, 2006.

Laak, D. v., Kolonien als "Laboratorien der Moderne”?, in Conrad, S., Osterhammel, J. (eds.), Das Kaiserreich transnational. Deutschland in der Welt 1871-1914, Göttingen, Vandenhoeck \& Ruprecht, 2004, pp. 257-279.

Lawrance, B. N., Osborn, E. L., Roberts, R. L., Introduction. African Intermediaries and the "Bargain" of Collaboration, in Lawrance, B. N., Osborn, E. L., Roberts, R. L., (eds.), Intermediaries, Interpreters and Clerks. African Employees in the Making of Colonial Africa, Madison, University of Wisconsin Press, 2006, pp. 3-34.

Lindenberger, T., Die "verdiente Tracht Prügel". Ein kurzes Kapitel über das Lynchen im wilhelminischen Berlin, in Lindenberger, T., Lüdtke, A. (eds.), Physische Gewalt. Studien zur Geschichte der Neuzeit, Frankfurt, Suhrkamp, 1995, pp. 190-212.

Lüdtke, A., Gemeinwohl und Festungspraxis, Göttingen, Vandenhoeck \& Ruprecht, 1982. 
Madley, B., From Africa to Auschwitz. How German South West Africa Incubated Ideas and Methods Adopted and Developed by the Nazis in Eastern Europe, European History Quarterly, 2005, 35, pp. 429-464.

Michels, E., Ein Feldzug - zwei Perspektiven? Paul von Lettow-Vorbeck und Heinrich Schnee über den ersten Weltkrieg in Ostafrika, in Epkenhans, M., Foerster, S., Hagemann, K. (eds.), Militärische Erinnerungskultur. Soldaten im Spiegel von Biographien, Memoiren und Selbstzeugnissen, Paderborn, Schöningh, 2006, pp. 152-168.

Mühleisen, S., Emil Schwörers Kolonial-Deutsch (1916). Sprachliche und historische Anmerkungen zu einem «geplanten» Pidgin im kolonialen Deutsch Südwest Afrika, Philologie im Netz, 2005, 31, pp. 30-48.

Nöckler, H. C., Sprachmischung in Südwestafrika, München, Hueber, 1963.

Oermann, N. O., Mission, Church and State Relation in South West Africa under German Rule (1884-1915), Stuttgart, Franz Steiner Verlag, 1999.

Oliver, R., Introduction, in Oliver, R., Sanderson, G.N. (eds.), The Cambridge History of Africa, Vol. VI, Cambridge, Cambridge University Press, 1985, pp. 1-9.

O'Donnel, K., Home, Nation, Empire. Domestic Germanness and Colonial Citizenship, in O'Donnel, K., Reagin, N., Bridenthal, R. (eds.), The Heimat abroad. The boundaries of Germanness, Ann Arbour, University of Michigan Press, 2005, pp. 40-57.

Osborne, E. L., 'Circle of Iron“. African Colonial Employees and the Interpretation of Colonial Rule in French West Africa, Journal of African History 2003, 44, pp., 29-50.

Osterhammel, J., Kolonialismus. Geschichte-Formen-Folgen, München, Beck, 2003.

Pesek, M., Die Grenzen des kolonialen Staates in Deutsch-Ostafrika, 1890-1914, in Chatriot, A., Gosewinkel, D. (eds.), Figurationen des Staates in Deutschland und Frankreich 1870-1945, München, Oldenbourg, 2006, pp. 117-140.

Pflanze, O., Bismarck. Der Reichskanzler, München, Beck, 1998.

Rafalski, H., Vom Niemandsland zum Ordnungsstaat. Die Geschichte der Kaiserlichen Landespolizei in DSWA, Berlin, Wernitz, 1930.

Roberts, R., Review of Miers/Klein (eds.), Slavery and colonial rule in Africa, 1999, Journal of African History 2000, 41, p. 307.

Schildknecht, J., Bismarck, Südwestafrika und die Kongokonferenz. Die völkerrechtlichen Grundlagen der effektiven Okkupation und ihre Nebenpflichten am Beispiel des Erwerbs der ersten deutschen Kolonie, Hamburg, Lit, 2000.

Shear, K., 'Taken as Boys'. The Politics of Black Police Employment and Experience in Early Twentieth-Century South Africa, in Lindsay, L. A., Miescher, St. (eds.), Men and masculinity in Africa, Portsmouth, Heinemann Educational Books, 2003, pp. 109-127.

Sippel, H., Typische Ausprägungen des deutschen kolonialen Rechts- und Verwaltungssystems in Afrika, in Voigt, R., Sack, P. (eds.), Kolonialisierung des Rechts. Zur kolonialen Rechts- und Verwaltungsordnung, Baden-Baden, Nomos, 2001, pp. 351-372.

Steinmetz, G., The devil's handwriting. Precoloniality and the German colonial state in Qingdao, Samoa, and Southwest Africa, Chicago, University of Chicago Press, 2007.

Sundermeier, Th., Mission, Bekenntnis und Kirche. Missionstheologische Probleme des 19. Jahrhunderts bei C.H. Hahn, Wuppertal, Verlag der Rheinischen Missionsgesellschaft, 1962.

Steinbach, A., Sprachpolitik und Zivilisierungsmission im Britischen Empire. Die Verbreitung der englischen Sprache im 19. Jahrhundert in Ceylon und den Protected Malay States, in Barth, B., Osterhammel, J. (eds.), Zvilisierungsmissionen. Imperiale Weltverbesserung seit dem 18. Jahrhundert, Konstanz, UvK, 2005, pp. 149-168. 
Tiebel, A., Die Entstehung der Schutztruppengesetze für die deutschen Schutzgebiete Deutsch-Ostafrika, Deutsch-Südwestafrika und Kamerun (1884-1898), Frankfurt a. M., Peter Lang Verlag, 2008.

Trotha, T.v., Koloniale Herrschaft. Zur soziologischen Theorie der Staatsentstehung am Beispiel des "Schutzgebietes Togo", Tübingen, Mohr Siebeck, 1994.

Vietsch, E. v., Wilhelm Solf. Botschafter zwischen den Zeiten, Tübingen, Rainer Wunderlich Verlag, 1961.

Walgenbach, K., Die Weiße Frau als Trägerin deutscher Kultur. Koloniale Diskurse über Geschlecht, "Rasse" und Klasse im Kaiserreich, Frankfurt am Main, Campus, 2005.

Wehler, H.-U., Krisenherde des Kaiserreichs 1871-1918, Göttingen, Vandenhoeck \& Ruprecht, 1970.

Wehler, H.-U., Deutsche Gesellschaftsgeschichte, Bd. 3. Von der 'Deutschen Doppelrevolution' bis zum Beginn des Ersten Weltkrieges 1849-1914, München, Beck, 1995.

Worger, W. H., Parsing God, Conversations about the meaning of words and metaphors in Nineteenth-century Southern Africa, Journal of African History, 2001, 42, pp. 417-447.

Zimmerer, J., Der totale Überwachungsstaat? Recht und Verwaltung in Deutsch-Südwestafrika, in Voigt, R., Sack, P. (eds.), Kolonialisierung des Rechts. Zur kolonialen Rechtsund Verwaltungsordnung, Baden-Baden, Nomos, 2001, pp. 183-207.

Zimmerer, J., Holocaust und Kolonialismus. Beitrag zu einer Genealogie des genozidalen Gedankens, Zeitschrift für Geschichte, 2003, 51, pp. 1098-1119.

Zimmerer, J., Deutsche Herrschaft über Afrikaner. Staatlicher Machtanspruch und Wirklichkeit im kolonialen Namibia, Münster, Lit Verlag, 2004a.

Zimmerer, J., Die Geburt des ,Ostlandes' aus dem Geiste des Kolonialismus. Ein postkolonialer Blick auf die NS-Eroberungs- und Vernichtungspolitik, SozialGeschichte. Zeitschrift für die historische Analyse des 20. und 21. Jahrhunderts, 2004b, 1, pp. 11-43.

Zimmerer, J., Rassenkrieg und Völkermord. Der Kolonialkrieg in Deutsch-Südwestafrika und die Globalgeschichte des Genozids, in Melber, H. (ed.), Genozid und Gedenken. Namibisch-deutsche Geschichte und Gegenwart, Frankfurt/M., Brandes \& Apsel, 2005, pp. 23-48. 